Dmytry Lega, PhD, Assistant, Department of Organic Chemistry, National University of Pharmacy, Pushkinska str., 53, Kharkiv, Ukraine, 61002

E-mail: orgchem@nuph.edu.ua

Valentine Chernykh, Doctor of Pharmaceutical Sciences, Doctor of Chemistry, Professor, Department of Organic Chemistry, National University of Pharmacy, Pushkinska str., 53, Kharkiv, Ukraine, 61002

E-mail: orgchem@nuph.edu.ua

Tetyana Osolodchenko, PhD, Senior Researcher, Head of Laboratory, Laboratory of Biochemistry and Biotechnology, Mechnikov Institute of Microbiology and Immunology NAMS of Ukraine, Pushkinska str., 14/16, Kharkiv, Ukraine, 61057

E-mail: imi_lbb@ukr.net

Leonid Shemchuk, Doctor of Chemistry, Professor, Head of Department, Department of Organic Chemistry National University of Pharmacy, Pushkinska str., 53, Kharkiv, Ukraine, 61002

E-mail: orgchem@nuph.edu.ua

УДК 582.683.2:581.4:547.92:543.544.3:543.51
DOІ: $10.15587 / 2519-4852.2017 .118169$

\title{
IDENTIFICATION AND QUANTITATIVE DETERMINATION OF STEROIDAL COMPOUNDS IN THE PLANT MATERIAL OF CABBAGE
}

\author{
M. Kuznetsova, O. Kyslychenko, I. Zhuravel
}

Овочеві культури є невичерпним джерелом біологічно активних речовин. Капуста городня (Brassica oleracea L.) - рослина, яка здавна застосовується в народній медицині багатьох країнах світу для лікування різноманітних захворювань, та проявляє протизапальну, відхаркувальну, бронхолітичну, сечогінну, загальнозміцнювальну дії. В Украӥні сировина капусти городньої є неофіцінальною і тому потребує комплексного фармакогностичного дослідження.

Мета. Ідентифікація та визначення кількісного вмісту стероїдних сполук у листі, насінні та качанах капусти городньої.

Методи дослідження. Ідентифікацію стероїдних сполук та визначення їх кількісного вмісту у сировині капусти городньої проводили методом газової хроматографії/мас-спектрометрї (ГХ/МС).

Результати дослідження. В результаті проведеного дослідження були ідентифіковані: у листі капусти городньої сорту «Білосніжка» - 3 сполуки стероїдної природи, сортів «Украйнська осінь» та «Ярославна» - 4, у насінні сорту «Білосніжка» - 4, сортів «Украӥнська осінь» та «Ярославна» - по 3 сполуки, у качанах всіх сортів виявлено по 3 стероїдних речовини. За кількісним вмістом в усіх досліджуваних зразках переважав $\beta$-ситостерол. Його найбільший вміст складав у листі (2499 мг/кг) та насінні (1728 мг/кг) сорту «Ярославна», а також у качанах (1148 мг/кг) сорту «Украӥнська осінь».

Висновки. Результати досліджень можуть бути використані при розробці методів контролю якості на сировину капусти городньої та при одержанні перспективних біологічно активних субстанцій з досліджуваної сировини

Ключові слова: капуста городня, листя, насіння, качани, стероїдні сполуки, газова хроматографія, мас/спектрометрія

\section{Introduction}

The study of crops as sources of medicinal preparations obtaining on their basis is actual for pharmacy nowadays. Cabbage (Brassica oleracea L.) is a member of the family Brassicaceae (or Cruciferae). In Ukraine it is grown as a vegetable culture, which has a sufficient raw material base and a big number of varieties. The complex of compounds contained in cabbage gives it many pharmacotherapeutic properties.

In folk medicine of the West and the East cabbage has long been used against various diseases. The leaves, roots, stumps, and seeds of the plant are use [1]. Cabbage juice is prescribed for gastritis and peptic ulcer of the stomach and duodenum, in ulcerative colitis, as well as in a mixture with honey in lung tuberculosis, in liver disor- ders. Roots and stumps are considered as an antitumor agent $[2,3]$. The decoction of the seeds is used for gout, pain in the joints, as an antiseptic and a diuretic. Folk medicine recommends that fresh leaves of cabbage can be applied to purulent wounds and ulcers, to the mammary glands during mastopathy. Cabbage leaves are also used for abscess and other inflammatory diseases of the skin, including burns [3]. Fiber contained in cabbage improves the motor function of the intestines, shows positive influence on gut microflora. The presence of group B vitamins in the fiber normalizes fat metabolism, promotes the removal of excess cholesterol, and inhibits the development of atherosclerotic plaques on the walls of the aorta and vessels of the heart, that is, helps in the treatment and prevention of atherosclerosis [4]. The 
expediency of using cabbage in medical practice is confirmed after its experimentally proved anti-ulcer properties $[2,3]$.

\section{Formulation of the problem in a general} way, the relevance of the theme and its connection with important scientific and practical issues

Many diseases are accompanied by inflammatory processes. It is known that anti-inflammatory activity is exhibited by such a class of biologically active compounds as steroids.

It has been established that in addition to antiinflammatory activity, phytosterols exhibit strong antisclerotic activity $[5,6]$. Investigation of plant sterols conducted in Finland, showed the presence of hypoglycemic effect of these compounds [7]. It has been established that the use of products containing phytosterols significantly reduces the risk of heart diseases $[8,9]$ and oncological diseases [2]. According to the literature data, in the medicine of different nations the raw materials of plants of the cabbage family are used to treat diseases that are accompanied by inflammatory processes $[10,11]$. Cabbage is one of the most valuable food products, which has always been considered as an effective and at the same time harmless therapeutic agent that increases the body's resistance to various diseases. Therefore, the study of steroidal compounds in leaves, seeds and stumps of cabbage can be expedient for their comprehensive study.

\section{Analysis of recent research and publications}

The analysis of literary sources showed that the cabbage reveals multi-vector pharmacological activity, in particular anti-inflammatory, antibacterial, expectorant, bronchodilatory, diuretic, general strengthening activity [11]. The plant contains carbohydrates, proteins, organic acids, sugars, vitamins, carotene, fatty acids, amino acids, cellulose, macro- and micro-elements, and other compounds $[4,10,12]$. The information on the study of steroidal compounds of cabbage is rather limited in available literature. Therefore, their study in the leaves, seeds and stumps of cabbage of the investigated varieties is of current interest.

\section{Identification of aspects of the problem un- solved previously \\ In Ukraine, cabbage is not a pharmacopoeial} plant. A detailed phytochemical study of leaves, seeds and stumps of cabbage, in particular steroidal compounds that exhibit anticancer and anti-inflammatory action, is necessary for the expansion of the range of medicinal plant material $[2,13]$.

\section{Formulation of article's tasks}

For the purpose of in-depth study the qualitative composition and quantitative content of steroidal compounds was determined by the GC/MS method in leaves, seeds and stumps of cabbage of "Snow White", "Ukrainian Autumn" and "Yaroslavna" varieties as they are in- cluded in the State Register of Plant Varieties, suitable for distribution in Ukraine, and are more widely cultivated in its territory.

\section{Presentation of the main material of the re-} search (methods and objects) with the justification of the results

The objects of the study were the leaves, seeds and stumps of white cabbage of "Snow White", "Ukrainian Autumn" and "Yaroslavna" varieties cultivated and harvested at the sites of the Institute of vegetables and gourd plantation of NAAS in 2016 in Kharkiv region.

The identification and quantification of steroidal compounds were carried out using gas chromatography / mass spectrometry (GC/MS) according to the procedure outlined below [14].

$0.05 \mathrm{~g}$ of crushed raw material was placed in $2 \mathrm{ml}$ vial, with adding $50 \mu \mathrm{g}$ of tridecane as an internal standard and $0.6 \mathrm{ml}$ of methylene chloride as a solvent. Vial was maintained for $3 \mathrm{~h}$ in an ultrasonic extractor or overnight at room temperature. The obtained extract was transferred to a vial of $2 \mathrm{ml}$ volume and concentrated by blowing with a flow of particularly pure nitrogen (flow rate of $100 \mathrm{ml} / \mathrm{min}$ ) to a residual extract volume of $10 \mu \mathrm{l}$. The introduction of the sample into a chromatographic column was carried out without separating the flow for 0.5 minutes, which allowed the sample to be introduced without loss separation and significantly increase the chromatographic sensitivity (in 10-20 times).

The experiment was conducted on chromatograph Agilent Technologies (USA) 6890 with a mass spectrometric detector 5973 with capillary column DB-5 (diameter $0.25 \mathrm{~mm}$, length $-30 \mathrm{~m}$ ). The velocity of the carrier gas (helium) was $1.2 \mathrm{ml} / \mathrm{min}$. The temperature of the inlet heater was $350{ }^{\circ} \mathrm{C}$, the temperature of the thermostat was programmed from $50{ }^{\circ} \mathrm{C}$ to $320{ }^{\circ} \mathrm{C}$ at a rate of $4 \mathrm{deg} / \mathrm{min}$.

The components were identified using NIST05 and WILEY 2007 mass spectrum libraries with a total of 470000 spectra in combination with programs for identifying AMDIS and NIST. Quantitative content of steroids (X, mg/kg) was determined by the method of internal standards by the formula:

$$
X=\frac{P_{1} \cdot 50}{P_{2} \cdot m},
$$

where $P_{1}$ is the area of the peak of the studied substance; 50 - the mass of the internal standard introduced as a sample, $\mu \mathrm{g}$;

$\mathrm{P}_{2}$ - the area of the peak of the standard; $\mathrm{m}$ - weight of raw materials, g.

Chromatograms of steroidal compounds in the leaves, seeds and stumps of cabbage are shown in Fig. 1-3. Results of determining the quantitative content of steroid compounds in the raw material of the studied plant are presented in Table. 1 


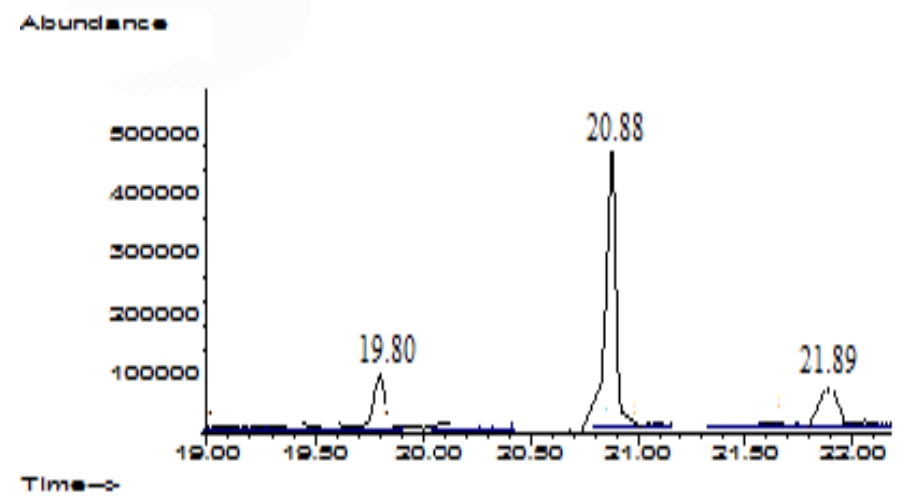

$a$
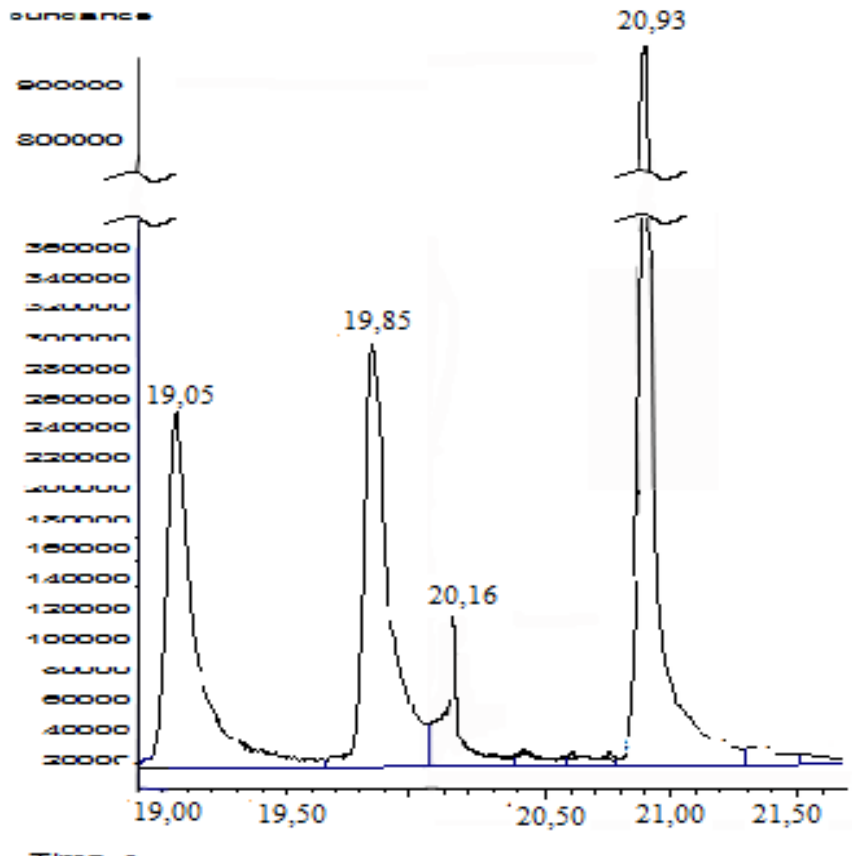

$b$

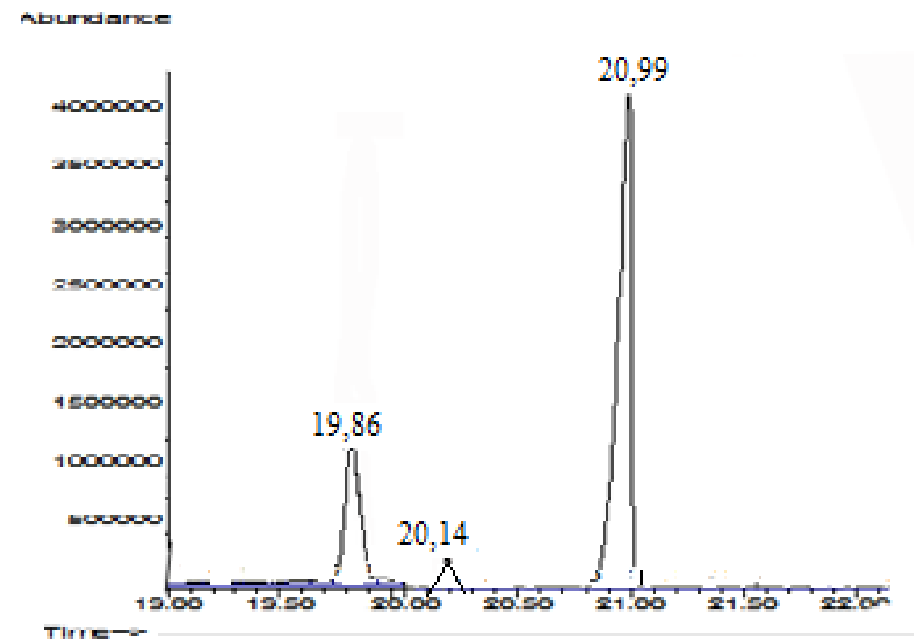

$c$

Fig. 1. Gas chromatograms of the determination of steroidal compounds of plant material of cabbage of "Snow White" variety: $a$ - leaves; $b$ - seeds; $c$ - stumps 

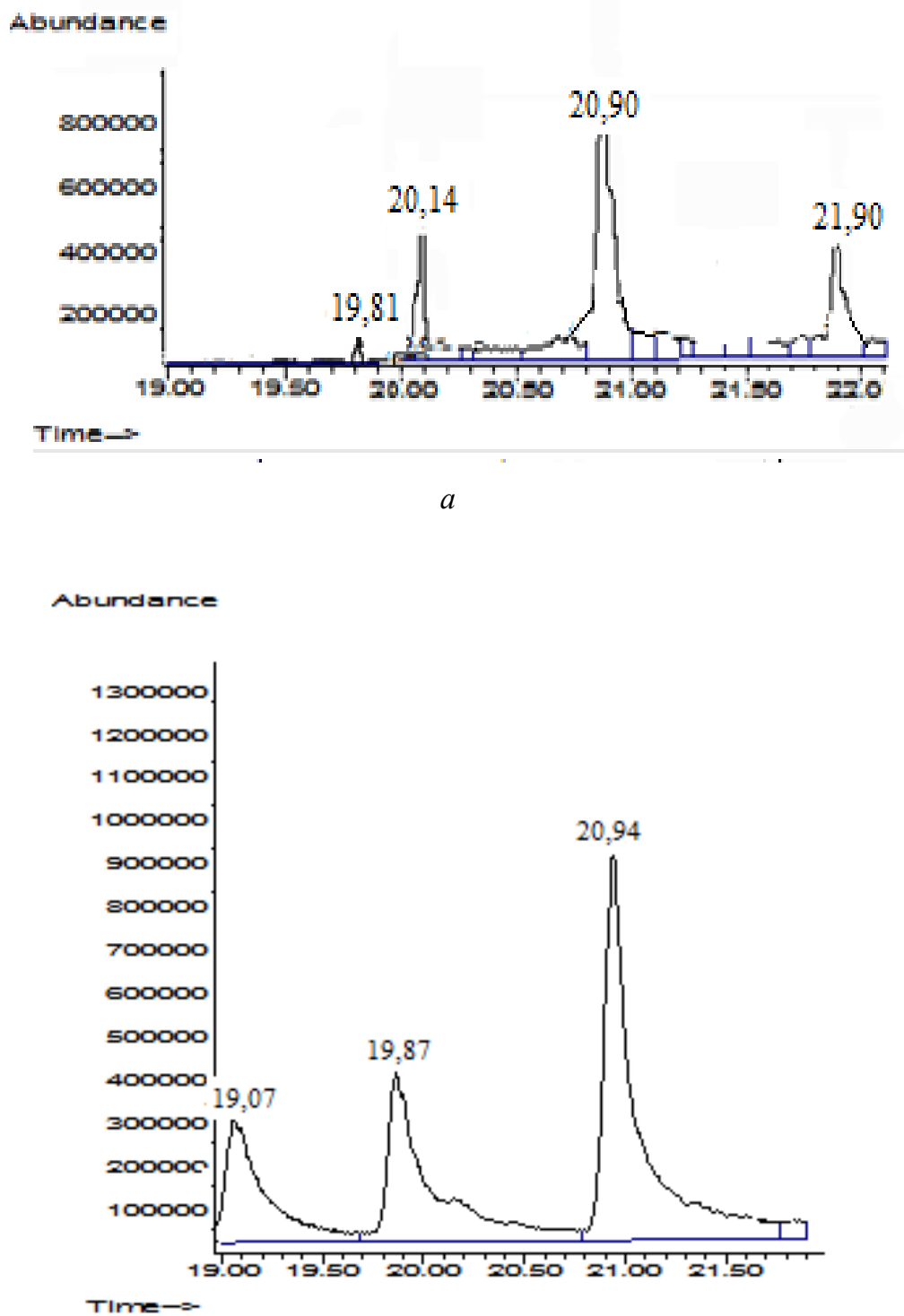

$b$

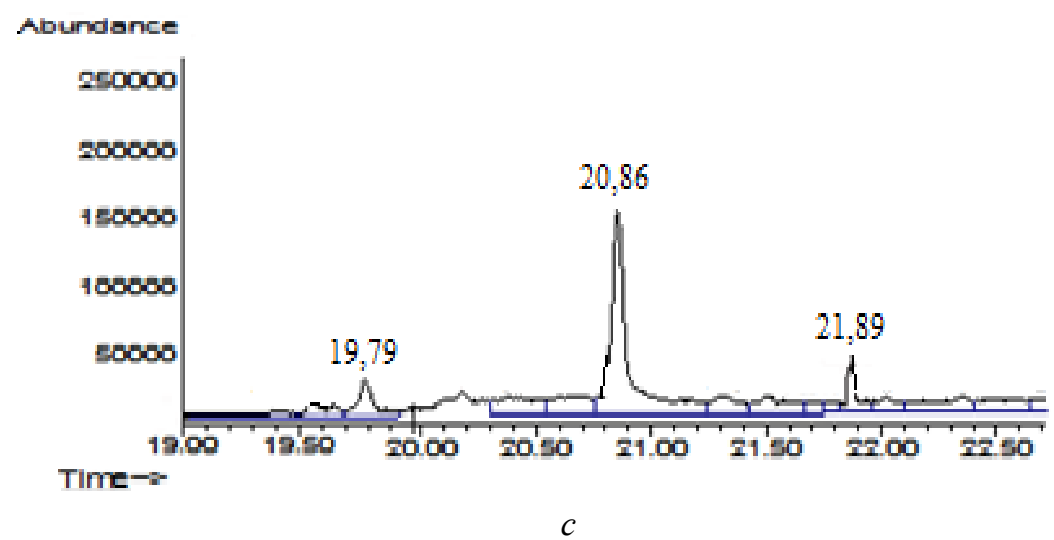

Fig. 2. Gas chromatograms of the determination of steroidal compounds of plant material of cabbage of "Ukrainian Autumn" variety: $a$ - leaves; $b$ - seeds; $c$-stumps 


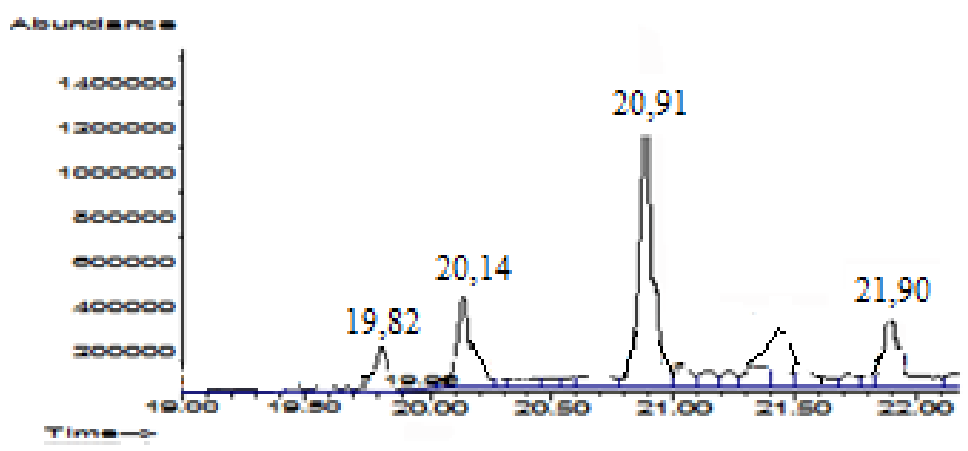

$a$
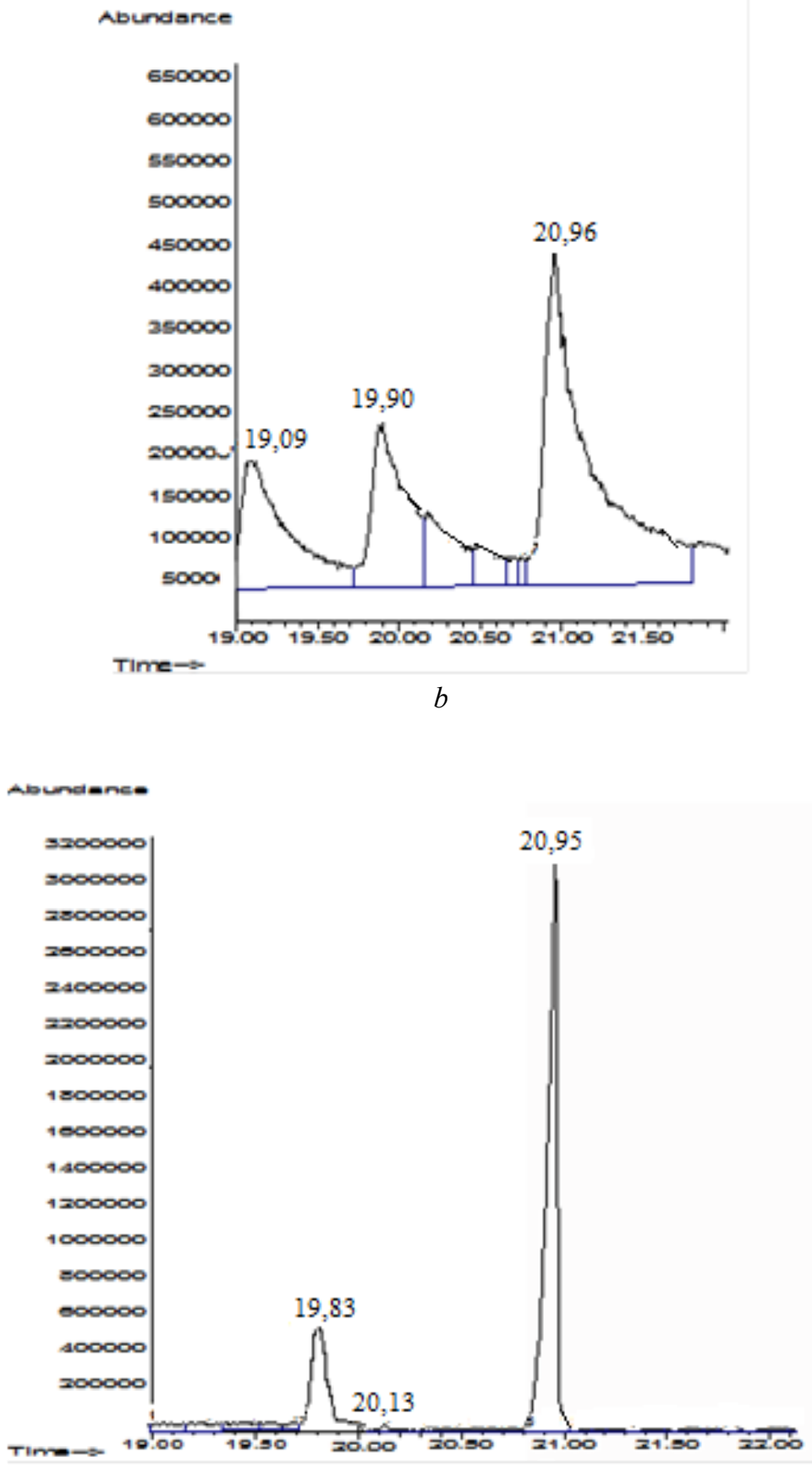

$c$

Fig. 3. Gas chromatograms of the determination of steroidal compounds of plant material of cabbage of "Yaroslavna" variety: $a$ - leaves; $b$ - seeds; $c$-stumps 
Quantitative content of steroidal compounds in the leaves, seeds and stumps of cabbage

\begin{tabular}{|c|c|c|c|c|c|c|c|c|c|c|c|c|c|c|c|c|c|c|c|}
\hline \multirow{4}{*}{ № } & \multirow{4}{*}{ Compound } & \multicolumn{18}{|c|}{ Retention time and quantitative content of steroidal compounds in the investigated plant material } \\
\hline & & \multicolumn{6}{|c|}{ leaves } & \multicolumn{6}{|c|}{ seeds } & \multicolumn{6}{|c|}{ stumps } \\
\hline & & \multicolumn{2}{|c|}{ Snow White } & \multicolumn{2}{|c|}{ Ukrainian Autumn } & \multicolumn{2}{|c|}{ Yaroslavna } & \multicolumn{2}{|c|}{ Snow White } & \multicolumn{2}{|c|}{ Ukrainian Autumn } & \multicolumn{2}{|c|}{ Yaroslavna } & \multicolumn{2}{|c|}{ Snow White } & \multicolumn{2}{|c|}{ Ukrainian Autumn } & \multicolumn{2}{|c|}{ Yaroslavna } \\
\hline & & \begin{tabular}{|l|} 
Retention \\
time, min
\end{tabular} & $\begin{array}{l}\text { Content, } \\
\mathrm{mg} / \mathrm{kg}\end{array}$ & $\begin{array}{l}\text { Retention } \\
\text { time, min }\end{array}$ & $\begin{array}{l}\text { Content, } \\
\mathrm{mg} / \mathrm{kg}\end{array}$ & $\begin{array}{l}\text { Retention } \\
\text { time, min }\end{array}$ & $\begin{array}{l}\text { Content, } \\
\mathrm{mg} / \mathrm{kg}\end{array}$ & $\begin{array}{l}\text { Retention } \\
\text { time, min }\end{array}$ & $\begin{array}{l}\text { Content, } \\
\mathrm{mg} / \mathrm{kg}\end{array}$ & $\begin{array}{l}\text { Retention } \\
\text { time, min }\end{array}$ & $\begin{array}{l}\text { Content, } \\
\mathrm{mg} / \mathrm{kg}\end{array}$ & $\begin{array}{l}\text { Retention } \\
\text { time, min }\end{array}$ & $\begin{array}{l}\text { Content, } \\
\mathrm{mg} / \mathrm{kg}\end{array}$ & $\begin{array}{l}\text { Retention } \\
\text { time, } \text { min }\end{array}$ & $\begin{array}{l}\text { Content, } \\
\mathrm{mg} / \mathrm{kg}\end{array}$ & $\begin{array}{l}\text { Retention } \\
\text { time, min }\end{array}$ & $\begin{array}{l}\text { Content, } \\
\mathrm{mg} / \mathrm{kg}\end{array}$ & $\begin{array}{l}\text { Retention } \\
\text { time, min }\end{array}$ & $\begin{array}{l}\text { Content, } \\
\mathrm{mg} / \mathrm{kg}\end{array}$ \\
\hline 1 & \begin{tabular}{|c} 
Ergosta- \\
5,22 -dien-3- \\
ol
\end{tabular} & - & - & - & - & - & - & 19.05 & 147.00 & 19.07 & 252.00 & 19.09 & 690.00 & - & - & - & - & - & - \\
\hline 2 & Campestrol & 19.80 & 39.00 & 19.82 & 138.00 & 19.82 & 496.00 & 19.85 & 153.00 & 19.87 & 387.00 & 19.90 & 623.00 & 19.86 & 52.00 & 19.79 & 230.00 & 19.83 & 46.00 \\
\hline 3 & $\begin{array}{c}\text { Stigmaste- } \\
\text { rol }\end{array}$ & - & - & 20.14 & 252.00 & 20.14 & 508.00 & 20.16 & 44.00 & - & - & - & - & 20.14 & 5.00 & 20.86 & 294.00 & 20.13 & 3.00 \\
\hline \begin{tabular}{|l|}
4 \\
\end{tabular} & $\beta$-sitosterol & 20.88 & 185.00 & 20.90 & 725.00 & 20.91 & 2499.00 & 20.93 & 440.00 & 20.94 & 485.00 & 20.96 & 1728.00 & 20.99 & 252.00 & 21.89 & 1148.00 & 20.95 & 274.00 \\
\hline 5 & $\beta$-Amyrin & 21.89 & 34.00 & 21.90 & 315.00 & 21.90 & 532.00 & - & - & - & - & - & - & - & - & - & - & - & - \\
\hline & $\begin{array}{l}\text { Amount of } \\
\text { identified } \\
\text { ompounds }\end{array}$ & - & 258.00 & - & 1430.00 & - & 4035.00 & - & 784.00 & - & 1124.00 & - & 3041.00 & - & 309.00 & - & 1672.00 & - & 323.00 \\
\hline
\end{tabular}

According to research results, 5 compounds of steroidal nature were identified in the cabbage plant material. In the leaves of "Snow White" cabbage variety 3 steroidal compounds were observed, in "Ukrainian Autumn" and "Yaroslavna" varieties -4 compounds. The presence of 4 compounds of steroidal nature was determined in the seeds of "Snow White" cabbage, "Ukrainian Autumn" and "Yaroslavna" varieties -3 compounds. Three types of steroids have been found in the stumps of all varieties.

As can be seen from the data in the table, the highest content of steroidal compounds was observed in the leaves and seeds of cabbage of "Yaroslavna" variety and comprised $4035.00 \mathrm{mg} / \mathrm{kg}$ and $3041.00 \mathrm{mg} / \mathrm{kg}$, respectively. A somewhat lower content of these compounds was found in the "Ukrainian Autumn" stumps, which was $1672.0 \mathrm{mg} / \mathrm{kg}$. The highest content of steroids was observed in the stumps of cabbage of "Ukrainian Autumn" variety $(1672.0 \mathrm{mg} / \mathrm{kg})$.

$\beta$-Sitosterol and campsterol are found in all types of raw materials, that is, in leaves, seeds and stumps of the studied varieties. The ergosta-5,22-dien-3-ol compound was detected only in the seeds of the studied varieties. Its highest content was observed in the seeds of "Yaroslavna" variety $(690.00 \mathrm{mg} / \mathrm{kg})$, much less - in "Ukrainian Autumn" (252.00 mg/kg) and "Snow White" ( $147.00 \mathrm{mg} / \mathrm{kg})$. The compound $\beta$-amyrin was found only in the leaves of cabbage of all the studied varieties. Its highest content was in the leaves of "Yaroslavna" $(532.00 \mathrm{mg} / \mathrm{kg})$ and "Ukrainian autumn" (315.00 mg/kg) varieties, the lowest - in the "Snow White" variety $34.00 \mathrm{mg} / \mathrm{kg}$.

At comparing the results of the research, it was found that $\beta$-sitosterol predominated among the dominant steroidal compounds in all objects. Its content was $2499 \mathrm{mg} / \mathrm{kg}$ in the leaves and $1748 \mathrm{mg} / \mathrm{kg}$ in seeds of
"Yaroslavna" variety, as well as in "Ukrainian Autumn" variety $1148 \mathrm{mg} / \mathrm{kg}$.

It should be noted that the total quantity of steroids in the raw material of cabbage of "Snow White" variety dominated in seeds $(784.00 \mathrm{mg} / \mathrm{kg})$ and stumps $(309,00 \mathrm{mg} / \mathrm{kg})$, for "Ukrainian autumn" varieties in the leaves $(1430.00 \mathrm{mg} / \mathrm{kg})$ and stumps $(1672.00 \mathrm{mg} / \mathrm{kg})$, for "Yaroslavna"variety - in the leaves $(4035.00 \mathrm{mg} / \mathrm{kg})$ and seeds $(3041.00 \mathrm{mg} / \mathrm{kg})$.

\section{Conclusions}

The article presents the results of experimental research on the identification and determination of the quantitative content of steroidal compounds in leaves, seeds and stumps of cabbage of "Snow White", "Ukrainian Autumn" and "Yaroslavna" Varieties.

1. Using the method of gas chromatography/mass spectrometry steroidal compounds in the raw material of cabbage were identified: in the leaves of "Snow White" variety - 3 compounds, in the leaves of "Ukrainian Autumn" and "Yaroslavna" varieties -4 compounds, in the seeds of "Snow White" variety - 4 compounds of steroidal nature, in the seeds of "Ukrainian Autumn" and "Yaroslavna" varieties - 3 compounds, in the stumps of all varieties the presence of 3 steroids is established. All kinds of investigated raw materials contained $\beta$-sitosterol and campsterol.

2. Quantitative content of steroidal compounds in the studied samples of plant material was determined. It was found that $\beta$-sitosterol dominated by content in all investigated raw materials.

3. The obtained experimental data can be used in the development of quality control methods for plant materials of cabbage of "White Snow", "Ukrainian Autumn" and "Yaroslavna" varieties.

\section{References}

1. Arnoldi, A. Functional foods, cardiovascular disease and diabetes [Text] / A. Arnoldi. - Cambridge: Woodhead Publishing, 2004. -488 p. doi: 10.1201/9781439823385

2. De Stefani, E. Plant Sterols and Risk of Stomach Cancer: A Case-Control Study in Uruguay [Text] / E. De Stefani, P. Boffetta, A. L. Ronco, P. Brennan, H. Deneo-Pellegrini, J. C. Carzoglio, M. Mendilaharsu // Nutrition and Cancer. - 2000. - Vol. 37, Issue 2. - P. 140-144. doi: 10.1207/s15327914nc372_4

3. Lockwood, B. Nutraceuticals: A quide for healthcare professionals. Vol. 5 [Text] / B. Lockwood. - London: Pharmaceutical Press, 2007. - P. 426.

4. Hall, R. D. Plant metabolomics applications in the brassicaceae: added value for science and industry [Text] / R. D. Hall, R. C. H. de Vos, J. L. Ward // Acta Horticulturae. - 2010. - Vol. 867. - P. 191-206. doi: 10.17660/actahortic.2010.867.24

5. Jesch, E. D. Food Ingredients That Inhibit Cholesterol Absorption [Text] / E. D. Jesch, T. P. Carr // Preventive Nutrition and Food Science. - 2017. - Vol. 22, Issue 2. - P. 67-80.

6. Ostlund, R. E. Inhibition of cholesterol absorption by phytosterol-replete wheat germ compared with phytosterol-depleted wheat germ [Text] / R. E. Ostlund, S. B. Racette, W. F. Stenson // The American Journal of Clinical Nutrition. - 2003. - Vol. 77, Issue 6. - P. 1385-1589. 
7. Valsta, L. M. Estimation of plant sterol and cholesterol intake in Finland: quality of new values and their effect on intake [Text] / L. M. Valsta, A. Lemstrom, M.-L. Ovaskainen, A.-M. Lampi, J. Toivo, T. Korhonen, V. Piironen // British Journal of Nutrition. - 2004. - Vol. 92, Issue 4. - P. 671-678. doi: 10.1079/bjn20041234

8. Gunstone, F. D. Fatty Acid and Lipid Chemistry [Text] / F. D. Gunstone. - Boston: Springer US, 1996. - P. 252-253. doi: 10.1007/978-1-4615-4131-8

9. Li, T. Phytosterol content of sea buckthorn (Hippophae rhamnoides L.) seed oil: Extraction and identification [Text] / T. Li, T. Beveridge, J. Drover // Food Chemistry. - 2007. - Vol. 101, Issue 4. - P. 1633-1639. doi: 10.1016/j.foodchem.2006.04.033

10. Samec, D. White cabbage (Brassica oleracea var. capitata f. alba): botanical, phytochemical and pharmacological overview [Text] / D. Samec, I. Pavlovic, B. Salopek-Sondi // Phytochemistry Reviews. - 2016. - Vol. 16, Issue 1. - P. 117-135. doi: 10.1007/s11101-016-9454-4

11. Singh, J. Antioxidant phytochemicals in cabbage (Brassica oleracea L. var. capitata) [Text] / J. Singh, A. K. Upadhyay, A. Bahadur, B. Singh, K. P. Singh, M. Rai // Scientia Horticulturae. - 2006. - Vol. 108, Issue 3. - P. 233-237. doi: 10.1016/j.scienta.2006.01.017

12. Park, S. Quantification of glucosinolates, anthocyanins, free amino acids, and vitamin $\mathrm{C}$ in inbred lines of cabbage (Brassica oleracea L.) [Text] / S. Park, M. Valan Arasu, M.-K. Lee, J.-H. Chun, J. M. Seo, S.-W. Lee et. al. // Food Chemistry. - 2014. Vol. 145. - P. 77-85. doi: 10.1016/j.foodchem.2013.08.010

13. Barnes, P. J. Anti-inflammatory actions of steroids: molecular mechanisms [Text] / P. J. Barnes, I. Adcock, M. Spedding, P. M. Vanhoutte // Trends in Pharmacological Sciences. - 1993. - Vol. 14, Issue 12. - P. 436-441. doi: 10.1016/01656147(93)90184-1

14. Dovhal, Ye. O. Identification and assay of steroid compounds in narrow-leaved catoptric raw material [Text] / Ye. O. Dovhal, I. G. Gurieva, V. S. Kyslychenko, I. O. Zhuravel // ScienceRise: Pharmaceutical Science. - 2016. - Vol. 3, Issue 3. P. 4-7. doi: 10.15587/2519-4852.2016.79473

Дата надходження рукопису 25.09.2017

Maryna Kuznetsova, Postgraduate student, Department of Chemistry of Natural Compounds, National University of Pharmacy, Pushkinska str., 53, Kharkiv, Ukraine, 61002

E-mail: kuznietsovamarina55@gmail.com

Oleksandra Kyslychenko, PhD, Associate Professor, Department of Pharmacognosy, National University of Pharmacy, Pushkinska str., 53, Kharkiv, Ukraine, 61002

E-mail: aleksandra.kyslychenko@gmail.com

Iryna Zhuravel, Doctor of Pharmaceutical Sciences, Professor, Department of Chemistry of Natural Compounds, National University of Pharmacy, Pushkinska str., 53, Kharkiv, Ukraine, 61002

E-mail: cnc@nuph.edu.ua 